\title{
ÚŘAD EVROPSKÉHO VEŘEJNÉHO ŽALOBCE A MEZINÁRODNÍ JUSTIČNÍ SPOLUPRÁCE VE VĚCECH TRESTNÍCH
}

\author{
PŘEMYSL POLÁK
}

\begin{abstract}
The European Public Prosecutor's Office and International Judicial Cooperation in Criminal Matters

This article explores the possible impact of the establishment of the European Public Prosecutor's Office (EPPO) on international judicial cooperation in criminal matters. The starting point is the clarification that the EPPO is the authority that does not exercise the criminal jurisdiction of the EU, but the criminal jurisdictions of the EU member states bound by Regulation (EU) 2017/1939. It means that not only the relations between the EPPO and the criminal jurisdictions of the EU member states not bound by Regulation (EU) 2017/1939 and between the EPPO and the criminal jurisdictions of non-member states of the EU have the character of international judicial cooperation in criminal matters, but also the internal relations within the EPPO between the criminal jurisdictions exercised by the EPPO. Each of the three different areas of international judicial cooperation in criminal matters is then separately analysed and the analyses are followed by concluding remarks. While the international judicial cooperation in criminal matters between the EPPO and the EU member states not bound by Regulation (EU) 2017/1939 will probably at least remain on the current level of judicial cooperation between the EU member states, the international judicial cooperation in criminal matters between the EPPO and non-member states of the $\mathrm{EU}$ is at risk of worsening (compared to the current level of judicial cooperation between the EU member states and non-member states of the EU), depending on the willingness of non-member states of the EU to cooperate with the EPPO as a new actor on the stage. On the other hand, the international judicial cooperation between the EU member states bound by Regulation (EU) 2017/1939, i. e. within the EPPO, might be better than the current level of judicial cooperation between the EU member states, partly due to the provisions of Regulation (EU) $2017 / 1939$ (although they are not too innovative) and partly due to the fact that higher level of willingness to cooperate is expected "under one roof" of the EPPO than between the authorities of various EU member states.
\end{abstract}

Keywords: European Public Prosecutor's Office (EPPO); international judicial cooperation in criminal matters; criminal jurisdiction; legal assistance; surrender of a person; extradition; transfer of criminal proceedings

Klíčová slova: Úřad evropského veřejného žalobce; mezinárodní justiční spolupráce ve věcech trestních; trestní jurisdikce; právní pomoc; předání osoby; extradice; předání trestního ř́zení

DOI: $10.14712 / 23366478.2019 .38$ 


\section{1. ÚVOD - VÝKON TRESTNÍ JURISDIKCE ÚŘADEM}

Cílem tohoto příspěvku je prozkoumat možné dopady zřízení Úřadu evropského veřejného žalobce (dále „Ưřad“) na oblast mezinárodní justiční spolupráce ve věcech trestních. Výchozím bodem je vyjasnění, jakou trestní jurisdikci bude Úřad vykonávat. V čl. 3 odst. 1 Nařízení Rady (EU) 2017/1939 ze dne 12. října 2017, kterým se provádí posílená spolupráce za účelem zřízení Ứradu evropského veřejného žalobce (dále „Nařízení“), je Úřad definován jako instituce Evropské unie (dále „EU“). Úkoly Úř̌adu jsou vymezeny v čl. 4 Nařízení. Úřad podle tohoto ustanovení odpovídá za vyšetřování, trestní stíhání a postavení před soud pachatelů a spolupachatelů trestných činů poškozujících nebo ohrožujících finanční zájmy EU, jež jsou stanoveny ve Směrnici Evropského parlamentu a Rady (EU) 2017/1371 ze dne 5. července 2017 o boji vedeném trestněprávní cestou proti podvodům poškozujícím finanční zájmy Unie (dále „Směrnice“) a vymezeny Nařízením. Ani Směrnice, ani Nařízení není evropským trestním zákoníkem. Směrnice podle svého čl. 1 pouze stanoví minimální pravidla týkající se vymezení trestných činů a trestních sankcí v oblasti boje proti podvodům a jinému protiprávnímu jednání poškozujícímu finanční zájmy EU, tedy minimální požadavky na to, co by $\mathrm{v}$ této oblasti mělo být $\mathrm{v}$ členských státech EU trestným činem a jaké by za něj měly být stanoveny trestní sankce. Pravomoc stanovit, co skutečně bude v členských státech EU v dané oblasti trestným činem a s jakými trestními sankcemi, zůstává jednotlivým členským státům EU, byt' při vázanosti minimálními pravidly stanovenými ve Směrnici. Nařízení nevymezuje trestné činy, pouze v souvislosti se stanovením věcné př́slušnosti Úřadu v čl. 22 odkazuje na trestné činy vymezené (především v souladu se Směrnicí) ve vnitrostátním právu členských států EU. Soudem, před který má Úřad podle čl. 4 Nařízení postavit pachatele a spolupachatele a před kterým má plnit úlohu veřejného žalobce, není žádný evropský soud, který by byl pro danou oblast trestné činnosti zř́izen, ale vnitrostátní soud př́slušného členského státu EU. Podle čl. 5 odst. 3 Nařízení se vyšetřování a trestní stíhání vedená jménem Úř̌adu řídí Nařízením a subsidiárně právem členského státu EU (zpravidla toho, jehož evropský pověřený žalobce případ projednává), přičemž $\mathrm{v}$ př́ípadě rozporu mezi Nařízením a vnitrostátním právem členského státu EU má přednost Nařízení. Nicméně Nařízení neobsahuje vlastní komplexní úpravu trestního procesu, a to ani v zárodečné formě, ale spíše jen úpravu některých dílč́ch aspektů trestního procesu. Trestní řízení vedené Úřadem, resp. jeho jménem se tedy bude v rozhodující míře řídit úpravou trestního procesu dotčeného členského státu EU, která bude Nařízením pouze částečně modifikována.

Jestliže jurisdikcí se obecně rozumí rozsah práva (státu) regulovat chování nebo následky událostí formou přijímání právních předpisů, rozhodování soudů nebo činnosti orgánů výkonné moci, resp. správních orgánů a tuto regulaci vynucovat, ${ }^{1}$ trestní jurisdikce by mohla být chápana jako právo (státu) stanovit, jaká jednání jsou trestnými činy a jaké trestní sankce lze za ně uložit, a uplatnit donucovací pravomoc vůči těm, kteří měli trestné činy spáchat, tj. zejména stíhat trestné činy, rozhodovat o vině a trestu a tato rozhodnutí vykonávat. $Z$ toho, jak byly v předchozím odstavci rozebrány úkoly Úřadu

1 Viz JENNINGS, R. - WATTS, A. (eds.). Oppenheim's International Law. 9th ed. Volume I- Peace, Introduction and Part I. Longman Group UK Limited and Mrs. Tamako Hudson, 1992, s. 456. 
a právní rámec vyšetřování a trestního stíhání vedených Ưřadem, resp. jeho jménem, je zřejmé, že v souvislosti se zrrízením Úřadu nevzniká samostatná trestní jurisdikce EU, ale že Úřad bude vykonávat trestní jurisdikce členských států EU, pro které je závazné Nařízení, a to společně s jinými orgány těchto států. Členské státy EU, pro které je závazné Nařízení, tak na základě čl. 86 Smlouvy o fungování EU a Nařízení nepřenesly na EU svou trestní jurisdikci v oblasti trestných činů poškozujících nebo ohrožujících finanční zájmy EU jako takovou, ale pouze EU, resp. Úřadu jakožto instituci EU částečně svěřily její výkon. V podmínkách České republiky to znamená, že vedle soustavy státního zastupitelství, které ukládá zastupování veřejné žaloby v trestním řízení (a výkon dalších úkolů stanovených zákonem) čl. 80 odst. 1 Ústavy, bude veřejnou žalobu $\mathrm{v}$ trestním řízení zastupovat $\mathrm{v}$ rozsahu své působnosti stanovené Nařízením Úřad.

Lze tedy shrnout, že Úřad je institucí EU, jejímž úkolem je podílet se jako orgán veřejné žaloby na výkonu trestní jurisdikce členských států EU, pro které je závazné Nařízení, ve vztahu k vymezeným trestným činům poškozujícím nebo ohrožujícím finanční zájmy EU. Skutečnost, že Úřad nebude vykonávat samostatnou trestní jurisdikci EU, ale trestní jurisdikce členských států EU, pro které je závazné Nař́zení, je zásadní pro určení rozsahu, v jakém se při fungování Úřadu uplatní mezinárodní justiční spolupráce ve věcech trestních.

\section{MEZINÁRODNÍ JUSTIČNÍ SPOLUPRÁCE VE VĚCECH TRESTNÍCH - VÝZNAM, SMYSL}

Mezinárodní justiční spoluprací ve věcech trestních se rozumí součinnost poskytovaná jedním státem druhému státu při výkonu jeho trestní jurisdikce. ${ }^{2}$ Pojem „mezinárodní justiční spolupráce ve věcech trestních" nahradil dříve používaný pojem „mezinárodní právní pomoc $\mathrm{v}$ trestních věcech ( $\mathrm{v}$ širším smyslu)“, který označoval pomoc cizozemských justičních orgánů při uskutečňování trestní pravomoci. ${ }^{3}$ Důvodem existence mezinárodní justiční spolupráce ve věcech trestních je skutečnost, že každému suverénnímu státu náleží územní výsost, tj. výlučná moc vůči všem osobám a věcem na jeho území, a jakékoli akty cizího státu jsou na jeho území zakázány, ledaže by k nim dal souhlas, ${ }^{4}$ přičemž všechny suverénní státy jsou si ve své suverenitě rovny - zásada svrchované rovnosti je modelem vztahů mezi státy. ${ }^{5}$ To znamená, že jeden stát nemůže

2 Vzhledem k zaměření tohoto př́spěvku lze ponechat stranou spolupráci států s mezinárodními trestními soudy nebo tribunály, která se do pojmu „mezinárodní justiční spolupráce ve věcech trestních“ rovněž řadí viz POLÁK, P. - KUBÍČEK, M. Vybrané koncepční změny obsažené v návrhu zákona o mezinárodní justiční spolupráci ve věcech trestních. In: Diskusni setkáni České národní skupiny Mezinárodní společnosti pro trestní právo, 18. 10. 2012 [cit. 2. 8. 2019]. Dostupné na: http://www.ok.cz/iksp/docs/aidp_121018 .pdf. O obsahu zmíněného pojmu ostatně vypovídá i samotný zákon č. 104/2013 Sb., o mezinárodní justiční spolupráci ve věcech trestních.

3 Viz KAMLACH, M. - REPÍK, B. Mezinárodni spolupráce v trestním a občanskoprávním rízení. Praha: Panorama, 1990, s. 46.

4 Viz POTOČNÝ, M. - ONDŘEJ, J. Mezinárodní právo veřejné, Zvláštní část. 4., dopl. a rožs. vyd. Praha: C. H. Beck, 2003, s. 14.

5 Viz MALENOVSKÝ, J. Mezinárodní právo veřejné, Jeho obecná část a poměr $k$ vnitrostátnímu právu, zvlášté k právu českému. 4., opr. a dopl. vyd. Brno: MU a nakladatelství Doplněk, s. 19. 
bez dalšího vykonávat svou trestní jurisdikci na území jiného státu. Přitom státy v souladu s mezinárodním právem uznávanými zásadami běžně stanoví působnost svých trestních zákonů i vůči skutkům, které byly spáchány mimo jejich území, ${ }^{6}$ a i když stát vykonává svou trestní jurisdikci vưči skutku spáchanému na jeho území, může být pro trestní řízení nezbytná osoba či věc, která se nachází na území jiného státu. ${ }^{7} \mathrm{~V}$ prostředí svrchované rovnosti jsou tedy státy nuceny poskytovat si při výkonu své trestní jurisdikce součinnost - uskutečňovat mezinárodní justiční spolupráci ve věcech trestních.

Má-li Úřad jako orgán veřejné žaloby plnohodnotně vykonávat trestní jurisdikce členských států EU, pro které je závazné Nařízení, musí být nastaveny jeho vztahy v oblasti mezinárodní justiční spolupráce ve věcech trestních navenek - ve vtahu k členským státům EU, pro které není závazné Nařízení, a k jiným než členským státům EU. Nebude-li ovšem Úřad vykonávat jednotnou trestní jurisdikci EU, ale trestní jurisdikce jednotlivých členských států EU, pro které je závazné Nařízení, pak i vztahy mezi jednotlivými trestními jurisdikcemi, které bude Úřad vykonávat, budou vztahy mezinárodní justiční spolupráce ve věcech trestních, ledaže by úprava vnitřních vztahů v rámci Úřadu v Nařízení nahradila mezinárodní justiční spolupráci ve věcech trestních jiným systémem spolupráce.

\section{MEZINÁRODNÍ JUSTIČNÍ SPOLUPRÁCE VE VĚCECH TRESTNÍCH MEZI ÚŘADEM A ČLENSKÝMI STÁTY EU, PRO KTERÉ NENÍ ZÁVAZNÉ NAŘÍZENÍ}

Mezinárodní justiční spolupráci ve věcech trestních mezi Úřadem a členskými státy EU, pro které není závazné Nařízení, by podle čl. 105 odst. 3 a bodu 110 preambule Nařízení měl do budoucna zřejmě upravit předpis EU, jehož návrh v případě potřeby předloží Evropská komise. Než se tak stane, jsou členské státy EU, pro které je závazné Nařízení, podle čl. 105 odst. 3 Nařízení povinny oznámit Úřad (v rozsahu jeho působnosti) jakožto orgán př́islušný k provádění příslušných předpisů EU o justiční spolupráci ve věcech trestních vưči členským státům EU, pro které není závazné Nařízení. ${ }^{8}$ Vstřícnost členských států EU, pro které není závazné Nařízení, k tomuto řešení a spolupráci s Úřadem by měla zajistit povinnost loajální spolupráce podle čl. 4 odst. 3 Smlouvy o EU, ${ }^{9}$ která je v této souvislosti výslovně zmíněna v bodu 110 preambule

Viz např. $\S 4$ až $§ 9$ trestního zákoníku.

7 Viz KAMLACH, M. - REPÍK, B. Mezinárodni spolupráce v trestním a občanskoprávním řizení. Praha: Panorama, 1990, s. 46.

8 Půjde zejména o předpisy EU jako Směrnice Evropského parlamentu a Rady 2014/41/EU ze dne 3. dubna 2014 o evropském vyšetřovacím př́kazu v trestních věcech či Rámcové rozhodnutí Rady ze dne 13. června 2002 o evropském zatýkacím rozkazu a postupech předávání mezi členskými státy (2002/584/SVV).

9 Čl. 4 odst. 3 Smlouvy o EU zní: „Podle zásady loajální spolupráce se Unie a členské státy navzájem respektují a pomáhají si při plnění úkolů vyplývajících ze Smluv.

Clenské státy učiní veškerá vhodná obecná nebo zvláštní opatření k plnění závazků, které vyplývají ze Smluv nebo z aktů orgánů Unie.

Členské státy usnadňují Unii plnění jejích úkolů a zdrží se všech opatř̌ení, jež by mohla ohrozit dosažení cílů Unie.“ 
Nařízení, takže ke zhoršení úrovně spolupráce by zde v důsledku převzetí výkonu trestní jurisdikce členských států EU, pro které je závazné Nařízení, Úřadem nemělo dojít.

\section{MEZINÁRODNÍ JUSTIČNÍ SPOLUPRÁCE VE VĚCECH TRESTNÍCH MEZI ÚŘADEM A JINÝMI NEŽ ČLENSKÝMI STÁTY EU}

Pokud jde o mezinárodní justiční spolupráci ve věcech trestních mezi Úřadem a jinými než členskými státy EU, předpokládá čl. 104 a bod 109 preambule Nařízení ćtyři různé modely, z nichž dva jsou postaveny na vlastních pravomocích EU, resp. Úřadu (viz dále body 4.1 a 4.4) a dva na stávající úrovni spolupráce členských státu EU, pro které je závazné Nařízení, s jinými než členskými státy EU (viz dále body 4.2 a 4.3).

\subsection{POUŽITÍ MEZINÁRODNÍ SMLOUVY, JEJIŽ SMLUVNÍ STRANOU BUDE EU}

V bodu 109 preambule Nařízení se předpokládá, že EU uzavře nové mezinárodní smlouvy v oblasti mezinárodní justiční spolupráce ve věcech trestních nebo přistoupí k mnohostranným mezinárodním smlouvám uzavřeným členskými státy EU v této oblasti, a čl. 104 odst. 3 Nařízení stanoví závaznost takových mezinárodních smluv pro Úřad. Účelem je vytvořit výslovný právní základ pro mezinárodní justiční spolupráci ve věcech trestních mezi Úřadem a jinými než členskými státy EU. Naplnění uvedeného předpokladu však představuje běh na dlouhou trat' a i při politické síle EU nemusí být jednoduché přesvědčit státy mimo EU, které budou z hlediska potřeb Úřadu v oblasti mezinárodní justiční spolupráce ve věcech trestních klíčové, k uzavření takových mezinárodních smluv. Navíc z mezinárodní justiční spolupráce ve věcech trestních bude pro Úřad rozhodující právní pomoc (v užším smyslu), tj. provedení procesních úkonů pro účely trestního řízení vedeného cizím státem, ${ }^{10}$ zejména za účelem opatření důkazu, doručení písemnosti, zajištění výnosů apod., a tu bude Úř̌ad spíše vyžadovat než poskytovat, nebot' v čl. 104 odst. 6 Nařízení se výslovně počítá pouze s tím, že Úřad může jiným než členským státům EU nebo mezinárodním organizacím poskytnout na základě žádosti jen informace nebo důkazy, které již má k dispozici, nikoli též s tím, že by na základě žádosti od takových subjektů prováděl úkony právní pomoci za účelem získání (nového) důkazu, doručení písemnosti, zajištění výnosů apod. Aby tedy práva a povinnosti stran z mezinárodní smlouvy o právní pomoci (v užším smyslu) mezi Úřadem a jiným než členským státem EU byly v rovnováze, musely by vyřizování žádostí jiného než členského státu EU o právní pomoc v podstatné míře zajišt'ovat orgány členských států EU, pro které je závazné Nařízení (uzavírat mezinárodní smlouvy o právní pomoci pouze $\mathrm{v}$ rozsahu odpovídajícím oprávnění Úřadu podle čl. 104 odst. 6 Nařízení zřejmě postrádá smysl).

10 Viz KAMLACH, M. - REPÍK, B. Mezinárodní spolupráce v trestním a občanskoprávním řizení. Praha: Panorama, 1990, s. 93. 


\subsection{OZNÁMENÍ ÚŘADU JAKO ORGÁNU PŘÍSLUŠNÉHO K PROVÁDĚNÍ MEZINÁRODNÍ SMLOUVY UZAVŘENÉ ČLENSKÝM STÁTEM EU}

Pro případ absence mezinárodní smlouvy uvedené v bodu 4.1 ukládá čl. 104 odst. 4 věta první Nařízení členským státům EU, pro které je závazné Nařízení, aby uznaly a oznámily Úřad jako orgán příslušný pro účely provádění mnohostranných mezinárodních smluv o právní pomoci v trestních věcech jimi uzavřených, a to i změnou těchto mezinárodních smluv, pokud je to nezbytné a možné. Tato povinnost členských států EU, pro které je závazné Nařízení, v souvislosti s níž bod 109 preambule Nařízení připomíná povinnost loajální spolupráce podle čl. 4 odst. 3 Smlouvy o EU, je ovšem podmíněna tím, že takový postup umožňuje př́slušná mnohostranná mezinárodní smlouva a že s ním jiné než členské státy EU souhlasí, když jiné než členské státy EU nejsou vůči EU vázány povinností loajální spolupráce a představa, že trestní jurisdikci některých členských států EU má namísto orgánů těchto států vykonávat Úřad jakožto instituce EU, tedy jiného subjektu mezinárodního práva, pro ně nemusí být automaticky akceptovatelná. Požadavek čl. 104 odst. 4 věty první Nařízení by nemusel představovat problém, bude-li realizován změnou prohlášení $\mathrm{k}$ mnohostranným mezinárodním smlouvám a nevyjádří-li jiné než členské státy EU - smluvní strany takových mezinárodních smluv s touto změnou nesouhlas. Změna mnohostranných mezinárodních smluv však znamená časově náročný proces s nejasným výsledkem, a proto obsahuje čl. 104 odst. 4 věta první dovětek ,pokud je to nezbytné a možné“ a v bodu 109 preambule Nařízení se uvádí, že renegociace by neměla být považována za povinný krok, nebot' není vždy možná. Podobně ani změna dvoustranných mezinárodních smluv nemusí být jednoduchá, a proto ve vztahu $\mathrm{k}$ jiným než mnohostranným mezinárodním smlouvám o právní pomoci v trestních věcech čl. 104 odst. 4 věta druhá Nařízení stanoví oznámení členských států EU, pro které je závazné Nařízení, že Úř̌ad je orgánem př́slušným k provádění těchto mezinárodních smluv, a to i jejich změnou, pouze jako možnost, nikoli jako povinnost.

\subsection{VYUŽITÍ OPRÁVNĚNÍ EVROPSKÉHO POVĚŘENÉHO ŽALOBCE PODLE VNITROSTÁTNÍHO PRÁVA DANÉHO ČLENSKÉHO STÁTU EU}

V situaci, kdy neexistuje mezinárodní smlouva uvedená v bodu 4.1 a kdy nelze využít ani mezinárodní smlouvu uvedenou v bodu 4.2, poskytuje čl. 104 odst. 5 Nařízení dvě možnosti. Podle prvního pododstavce čl. 104 odst. 5 Nařízení může evropský pověřený žalobce, který př́pad projednává, využít svých pravomocí vnitrostátního žalobce daného členského státu EU a požádat o právní pomoc $\mathrm{v}$ jiném než členském státě EU na základě mezinárodní smlouvy uzavřené daným členským státem EU nebo v bezesmluvním styku - na základě vnitrostátního práva daného členského státu EU, a to případně i prostř̌ednictvím př́slušných vnitrostátních orgánů (tj. zřejmě orgánů, jejichž prostřednictvím se předávají žádosti justičních orgánů daného členského státu EU o právní pomoc cizozemským orgánům). K druhé možnosti podle čl. 104 odst. 5 Nařízení viz bod 4.4. Podle čl. 13 odst. 1 Nařízení totiž evropští pověření žalobci mají (vedle pravomocí a postavení vyplývajících z Nařízení) stejné pravomoci jako vnitrostátní 
žalobci, pokud jde o vyšetřování, trestní stíhání a podání obžaloby. V takovém případě však evropský pověřený žalobce musí dožádaný stát informovat, že důkazy získané na základě žádosti budou použity Úřadem pro účely Nařízení, resp. požádat dožádaný stát o souhlas s tímto použitím. Právě tato potřeba zajistit širší využitelnost výsledku právní pomoci než $\mathrm{v}$ př́ípadě žádosti vnitrostátního justičního orgánu může vyřízení žádosti o právní pomoc $\mathrm{v}$ jiném než členském státě EU komplikovat. Lze si představit, že jiný než členský stát EU odmítne právní pomoc poskytnout nebo omezí využitelnost jejích výsledků pouze na orgány členského státu EU, v němž působí dožadující evropský pověřený žalobce, aby zabránil tomu, že výsledek právní pomoci bude využitelný v rámci (potenciálně celého) Úřadu nebo jiným členským státem EU, než je členský stát EU dožadujícího evropského pověřeného žalobce, např. v důsledku rozhodnutí o předání př́padu jinému evropskému pověřenému žalobci v jiném členském státě $E U$, sloučení či rozdělení príípadu podle čl. 26 odst. 5 Nařízení nebo rozhodnutí o členském státě EU, v němž má být príípad předložen $\mathrm{k}$ trestnímu stíhání, či o spojení případů podle čl. 36 odst. 3, 4 Nařízení.

Podobná konstrukce byla přijata u vyžádání osoby z jiného než členského státu EU, kde čl. 104 odst. 7 Nařízení dává evropskému pověřenému žalobci, který př́ípad projednává, oprávnění požádat př́slušný orgán svého státu, aby podal žádost o vydání v souladu s mezinárodní smlouvou nebo vnitrostátním právem. Ostatně půjde o vydání osoby do členského státu EU, jehož jurisdikci Úřad vykonává, nikoli o vydání osoby Úřadu či EU.

\subsection{VYŽÁDÁNÍ PRÁVNÍ POMOCI ÚŘADEM V BEZESMLUVNÍM STYKU}

Druhým možným řešením situace, kdy neexistuje mezinárodní smlouva uvedená v bodu 4.1 a kdy nelze využít ani mezinárodní smlouvu uvedenou v bodu 4.2, je podle čl. 104 odst. 5 druhého pododstavce Nařízení, že sám Úřad požádá jiný než členský stát EU o právní pomoc v bezesmluvním styku. Zmíněné ustanovení Nařízení $\mathrm{v}$ této souvislosti pouze stanoví, že Úřad dodrží podmínky stanovené orgány jiných než členských států EU ohledně použití informací, které byly na tomto základě poskytnuty. V bodu 109 preambule Nařízení se k této možnosti uvádí, že Úřad by měl mít možnost ve vztahu k orgánům jiných než členských států EU spoléhat na vzájemnost nebo mezinárodní zdvořilost $\mathrm{s}$ tím, že tato možnost by měla být realizována př́ípad od př́ípadu, $\mathrm{v}$ mezích věcné př́slušnosti Úřadu a v závislosti na př́padných podmínkách stanovených orgány jiných než členských států EU. Pokud mezinárodní zdvořilost představuje dobrovolně (,ze zdvořilosti“) provedené ústupky ${ }^{11}$ či pravidla slušnosti, vhodnosti a dobré vůle, kterými se státy (či jiné subjekty mezinárodního práva) řídí ve svých vztazích, i když nejsou právně závazná, ${ }^{12}$ nejeví se zde zmínka o mezinárodní zdvořilosti jako zcela př́ípadná. Otázka, zda stát využije svou donucovací pravomoc v trestním

11 Viz SEIDL-HOHENVELDERN, I. Mezinárodni právo veřejné. Praha: CODEX Bohemia, s. r. o., 1999, s. 94.

12 Viz JENNINGS, R. - WATTS, A. (eds.). Oppenheim's International Law. 9th ed. Volume I - Peace, Introduction and Part I. Longman Group UK Limited and Mrs. Tamako Hudson, 1992, s. 51. 
ř́zení vůči osobám na svém území pro účely trestního řízení vedeného v jiném státě, by neměla být otázkou mezinárodní zdvořilosti v uvedeném smyslu, ale primárně otázkou podmínek stanovených právním řádem dožádaného státu (přinejmenším v právním státě). Zmínku o mezinárodní zdvořilosti je tedy možné chápat spíše jako vyjádření skutečnosti, že vyhovění žádosti Úřadu o právní pomoc v bezesmluvním styku jiným než členským státem EU plně závisí na podmínkách stanovených právním řádem dožádaného státu. Začasté bude jednou z těchto podmínek poskytnutí záruky vzájemnosti, tedy ujištění dožadující strany, že by v obdobném př́ípadě požadovanou pomoc dožádanému státu rovněž poskytla. Poskytování takové záruky Ứ̛̌adem není Nařízením blíže upraveno, což lze vnímat jako závažný nedostatek, nebot' může-li Úřad podle čl. 104 odst. 6 Nařízení jiným než členským státům EU nebo mezinárodním organizacím poskytnout na základě žádosti jen informace nebo důkazy, které již má k dispozici, nikoli též provádět na základě žádosti od takových subjektů úkony právní pomoci za účelem získání (nového) důkazu, doručení písemnosti, zajištění výnosů apod., lze předpokládat, že záruka vzájemnosti poskytnutá Úřadem bude bud' velmi úzká (bude-li vycházet pouze z oprávnění podle čl. 104 odst. 6 Nařízení), nebo bude muset (s ohledem na povinnost loajální spolupráce podle čl. 4 odst. 3 Smlouvy o EU) zavazovat orgány členských států EU, pro které je závazné Nařízení, pokud jde o poskytnutí ekvivalentní právní pomoci státu dožádanému Úřadem. Dotčeným členským státům EU, pro které je závazné Nařízení, by proto $\mathrm{v}$ takovém případě měla být dána možnost poskytnutí záruky vzájemnosti Úřadem ovlivnit nebo alespoň předložit své odůvodněné stanovisko k jejímu poskytnutí.

\section{MEZINÁRODNÍ JUSTIČNÍ SPOLUPRÁCE VE VĚCECH TRESTNÍCH V RÁMCI ÚŘADU}

\subsection{MYŠLENKA JEDNOTNÉ PRÁVNÍ OBLASTI}

Podle původní koncepce evropského veřejného žalobce v rámci projektu Corpus Juris mělo pro účely vyšetřování, trestního stíhání, řízení před soudem a výkonu rozhodnutí ve vztahu $\mathrm{k}$ trestným činům spadajícím do působnosti evropského veřejného žalobce území členských států EU tvořit tzv. jednotnou právní oblast. Tato fikce jednotného evropského území, resp. jednotné evropské jurisdikce znamenala, že jednotliví evropští veřejní žalobci by vykonávali svou pravomoc na území všech členských států EU (v rámci celé jednotné právní oblasti) jako tzv. „putujíci““ žalobci, že evropský zatýkací rozkaz vydaný na žádost evropského veřejného žalobce národním soudcem by byl platný na území všech členských států EU (v rámci celé jednotné právní oblasti) a zatčená osoba by mohla být přemístěna do členského státu EU, v němž by její př́ítomnost byla potřebná, a stejně tak i rozhodnutí soudů členských států EU o trestných činech spadajících do působnosti evropského veřejného žalobce by byla platná na území všech členských států EU (v rámci celé jednotné právní oblasti). Tímto způsobem chtěli autoři projektu Corpus Juris mezi členskými státy EU ohledně trestných činů spadajících do působnosti evropského veřejného žalobce zcela nahradit zdlouhavé a složité 
postupy mezinárodní justiční spolupráce ve věcech trestních (zejména právní pomoci a extradice). ${ }^{13}$

Touto koncepcí byl částečně inspirován i původní návrh Nařízení. ${ }^{14} \mathrm{~V}$ čl. 25 odst. 1 tohoto návrhu bylo stanoveno, že pro účely vyšetřování a stíhání vedených Úřadem se území členských států EU považuje za jeden právní prostor, v němž může Úřad vykonávat svou působnost. Pro tzv. přeshraniční př́ípady, kdy bylo třeba provést úkon v jiném členském státě EU, než ve kterém bylo vyšetřování zahájeno, však nebylo v čl. 18 odst. 2 návrhu evropskému pověřenému žalobci, který vyšetřování vedl, svěreno oprávnění provést takový úkon na území jiného členského státu EU samostatně, ale v úzké konzultaci s evropským pověřeným žalobcem ze státu, ve kterém měl být úkon proveden, kterému bylo uloženo, aby úkon provedl sám nebo předal pokyny k jeho provedení př́slušným vnitrostátním orgánům. Evropský veřejný žalobce pak mohl podle čl. 18 odst. 3 návrhu pověřit evropské pověřené žalobce $\mathrm{z}$ různých členských států EU provedením úkonů jeho jménem nebo podle čl. 18 odst. 6 návrhu provádět úkony v různých členských státech EU sám, vždy za vyrozumění evropského pověřeného žalobce $\mathrm{z}$ daného členského státu EU a v součinnosti s vnitrostátními orgány daného členského státu EU, kterým zůstalo vyhrazeno provádění donucovacích opatření.

\subsection{USTANOVENÍ NAŘÍZENÍ O PŘESHRANIČNÍM VYŠETŘOVÁNÍ A PŘESHRANIČNÍM PŘEDÁVÁNÍ}

Z ustanovení Nařízení o přeshraničním vyšetřování (čl. 31 a 32) a přeshraničním předávání (čl. 33 odst. 2) je zřejmé, že koncepce jednotné právní oblasti se do konečného znění Nařízení neprosadila a vztahy mezi jednotlivými trestními jurisdikcemi, které bude Úřad vykonávat, budou mít povahu mezinárodní justiční spolupráce ve věcech trestních.

U právní pomoci (v užším smyslu) se v Nařízení projevuje snaha nahradit v trestních řízeních vedených Ứradem mezi členskými státy EU, pro které je závazné Nařízení, instituty žádosti o právní pomoc ${ }^{15}$ a evropského vyšetřovacího př́kazu ${ }^{16}$ vlastním mechanismem. Pokud evropský pověřený žalobce, který případ projednává, potřebuje provést úkon právní pomoci (nařízení v této souvislosti hovoří o opatření) v jiném členském státě EU, pro který je závazné Nařízení, rozhodne podle čl. 31 odst. 1 Nařízení o přijetí opatření a přidělí je evropskému pověrenému žalobci v členském státě EU, v němž má být toto opatření provedeno. Odůvodnění a přijetí opatření se podle čl. 31 odst. 2 Nařízení ŕídí právem členského státu EU evropského pověřeného žalobce, který případ

13 Viz DELMAS-MARTY, M. Corpus Juris - Introducing Penal Provisions for the Purpose of the Financial Interests of the European Union. Paris: Economica, 1997, s. 82-86 a 106, a FENYK, J. - JÍLEK, D. „Evropská právní oblast“ a Corpus Iuris jako možné nástroje ochrany finančních zájmů Evropských společenství. Trestni právo, 1997, č. 11, Př́iloha Z trestněprávní praxe XI., s. I-IV.

14 Viz Návrh Nařízení Rady o zřízení Úřadu evropského veřejného žalobce, Brusel, 17. 7. 2013, COM(2013) 534 final, 2013/0255 (APP).

15 Ve vztazích mezi členskými státy EU viz zejména Evropskou úmluvu o vzájemné pomoci ve věcech trestních ze dne 20. dubna 1959 a její dodatky, především Úmluvu o vzájemné pomoci v trestních věcech mezi členskými státy Evropské unie ze dne 29. května 2000.

16 Viz Směrnici Evropského parlamentu a Rady 2014/41/EU ze dne 3. dubna 2014 o evropském vyšetřovacím príkazu v trestních věcech. 
projednává. Evropský pověřený žalobce, jemuž bylo opatření přiděleno (tzv. pomocný evropský pověřený žalobce), podle čl. 31 odst. 4 Nařízení opatření provede nebo nařídí př́slušnému vnitrostátnímu orgánu, aby tak učinil. Při výkonu přiděleného opatření se podle čl. 32 Nařízení postupuje v souladu s Nařízením a právem členského státu EU pomocného evropského pověřeného žalobce s povinností dodržet formální náležitosti a postupy výslovně uvedené evropským pověřeným žalobcem, který př́pad projednává, pokud nejsou v rozporu se základními právními zásadami členského státu EU pomocného evropského pověřeného žalobce. Výčet důvodů pro neprovedení přiděleného opatření v čl. 31 odst. 5 Nařízení je poměrně úzký (má 4 body), lhůta pro jeho provedení v čl. 31 odst. 7 Nařízení (obecně 7 pracovních dnů) je velmi krátká a při jejím nedodržení se má věc předat stálé komoře, která je podle čl. 31 odst. 8 Nařízení oprávněna rozhodnout, zda a v jaké lhůtě bude přidělené opatření nebo náhradní opatření provedeno. $V$ čl. 31 odst. 6 Nařízení je stanovena možnost subsidiární použitelnosti právních nástrojů o vzájemném uznávání nebo přeshraniční spolupráci, pokud přidělené opatření v čistě vnitrostátní situaci neexistuje, ale bylo by k dispozici v situaci přeshraniční, kterou tyto právní nástroje upravují. Př́íladem takového přeshraničního opatření, resp. úkonu budiž výslech prostřednictvím videokonferenčního zařízení nebo telefonu, ${ }^{17} \mathrm{kte}-$ rý je specifický nejen užitím těchto technických prostředků, k němuž běžně dochází i v čistě vnitrostátním trestním řízení, ale zejména tím, že jejich prostřednictvím provádí nebo vede výslech osoby $\mathrm{v}$ dožádaném či vykonávajícím státě přímo justiční orgán dožadujícího či vydávajícího státu, a to podle svého právního řádu, ovšem v mezích základních zásad právního řádu dožádaného či vykonávajícího státu, na jejichž zachovávání dohlíží domácí justiční orgán; vůči dožádanému či vykonávajícímu státu tak představuje tento úkon průlom do zásady státní suverenity a do zásady locus regit actum. ${ }^{18}$

Popsaný mechanismus právní pomoci (v užším smyslu) v rámci Úřadu svým pojetím nijak zvlášt' nevybočuje z pravidel právní pomoci (v užším smyslu) na základě žádosti nebo evropského vyšetřovacího př́kazu. Ostatně „obecné“ právní nástroje o vzájemném uznávání nebo přeshraniční spolupráci se zde uplatní subsidiárně. Místo žádosti o právní pomoc či evropského vyšetřovacího př́kazu je zde rozhodnutí o přijetí opatření a jeho přidělení evropskému pověřenému žalobci z jiného členského státu EU (fakt, že se o přijetí opatření rozhoduje, naznačuje spíše blízkost tohoto mechanismu institutům mezinárodní justiční spolupráce ve věcech trestních mezi členskými státy EU postaveným na zásadě vzájemného uznávání rozhodnutí, byt' tomuto rozhodnutí nekoresponduje výslovně stanovená procedura rozhodování o uznání a výkonu ve státě pomocného evropského pověřeného žalobce). Nicméně přidělené opatření provádí výlučně pomocný evropský pověřený žalobce z členského státu EU, na jehož území má být opatření provedeno, nebo vnitrostátní orgán tohoto státu a postupuje při tom podle Nařízení (které toho v tomto směru mnoho nestanoví) a svého vnitrostátního práva, přičemž formální náležitosti a postupy výslovně uvedené evropským pověřeným ža-

17 Viz čl. 10 a 11 Úmluvy o vzájemné pomoci v trestních věcech mezi členskými státy Evropské unie ze dne 29. května 2000 a čl. 24 a 25 Směrnice Evropského parlamentu a Rady 2014/41/EU ze dne 3. dubna 2014 o evropském vyšetřovacím př́kazu v trestních věcech.

18 Viz KUBÍČEK, M. - POLÁK, P. Zákon o mezinárodní justiční spolupráci ve věcech trestních. Komentár. Praha: Wolters Kluwer, a. s., 2014, s. 160-161. 
lobcem, který případ projednává, musí dodržet, pokud nejsou v rozporu se základními právními zásadami jeho vnitrostátního práva. ${ }^{19}$ Výhodu tak oproti právní pomoci (v užším smyslu) na základě žádosti nebo evropského vyšetřovacího př́kazu představuje především skromný výčet důvodů pro neprovedení přiděleného opatření a minimální lhůta pro provedení přiděleného opatření, což ovšem nejsou projevy systémových rozdílů, ale spíše nastavení systému, jakož i zapojení „nadřízeného“ orgánu v podobně stálé komory do tohoto mechanismu právní pomoci (v užším smyslu). Toto zapojení stálé komory již systémovým rozdílem je, nebot' stálá komora může svým autoritativním rozhodováním dovést dotčené evropské pověřené žalobce z různých členských států EU poměrně rychle ke konstruktivnímu řešení a něco takového je mimo rámec Úřadu u právní pomoci (v užším smyslu) na základě žádosti nebo evropského vyšetřovacího prríkazu nepředstavitelné. Avšak ani stálá komora nemůže svým autoritativním rozhodováním překonat všechny objektivní překážky poskytnutí spolupráce na základě rozhodnutí o přijetí opatření a jeho přidělení evropskému pověřenému žalobci z jiného členského státu EU, které mohou mít objektivní příčiny dané např. rozdíly v právních rrádech dotčených členských států EU.

U předání osoby (dříve extradice), tj. předání osoby státem, na jehož území se nachází, do státu, na jehož území je trestně stíhána nebo byla odsouzena, za účelem trestního stíhání nebo výkonu trestu, ${ }^{20}$ se podle Nařízení v trestních ř́zeních vedených Úřadem mezi členskými státy EU, pro které je závazné Nařízení, plně uplatní předání na základě evropského zatýkacího rozkazu, ${ }^{21}$ když čl. 33 odst. 2 Nařízení dává evropskému pověřenému žalobci oprávnění vydat evropský zatýkací rozkaz nebo požádat př́íslušný orgán daného členského státu EU o jeho vydání (zřejmě v závislosti na rozsahu oprávnění vnitrostátního žalobce daného členského státu EU). U tohoto druhu mezinárodní justiční spolupráce ve věcech trestních tak Nařizení nepřináší žádný vyšší standard oproti obecné úrovni spolupráce mezi členskými státy EU. Lze ovšem připomenout, že původní koncepce evropského veřejného žalobce v rámci projektu Corpus Juris byla jedním z inspiračních zdrojů institutu evropského zatýkacího rozkazu, který v mezidobí nahradil mezi členskými státy EU extradici. Myšlenka evropského zatýkacího rozkazu $\mathrm{z}$ tohoto projektu se sice neprosadila $\mathrm{v}$ radikální podobě fikce jednotného evropského území, resp. jednotné evropské jurisdikce, ale jako forma spolupráce mezi jurisdikcemi jednotlivých členských států EU, ovšem nikoli jen ve vztahu k omezenému okruhu trestných činů, ale jako obecná forma spolupráce.

Jiné druhy mezinárodní justiční spolupráce ve věcech trestních mezi členskými státy EU, pro které je závazné Nařízení, v trestních řízeních vedených Ứradem nejsou v Nařízení výslovně upraveny. Některé úkony v rámci Úřadu však mají rysy předání trestního řízení, kdy stát, který vede trestní řízení, se vzdává výkonu své trestní jurisdikce, tedy

19 Stejný právní režim provádění úkonů právní pomoci dožádaným, resp. vykonávajícím státem je stanoven v čl. 4 Úmluvy o vzájemné pomoci v trestních věcech mezi členskými státy Evropské unie ze dne 29. května 2000 a čl. 9 odst. 1 a 2 Směrnice Evropského parlamentu a Rady 2014/41/EU ze dne 3. dubna 2014 o evropském vyšetřovacím př́ḱkazu v trestních věcech.

20 Viz KAMLACH, M. - REPÍK, B. Mezinárodní spolupráce v trestním a občanskoprávním ř́zení. Praha: Panorama, 1990, s. 51.

21 Viz Rámcové rozhodnutí Rady ze dne 13. června 2002 o evropském zatýkacím rozkazu a postupech předávání mezi členskými státy (2002/584/SVV). 
práva vést trestní řízení, aby umožnil toto právo vykonat jinému státu namísto sebe. ${ }^{22}$ Takovým úkonem je zejména rozhodnutí stálé komory o předání prrípadu evropskému pověřenému žalobci v jiném členském státě EU nebo o sloučení či rozdělení príípadu a výběru evropského pověreného žalobce, který jej projedná, podle čl. 26 odst. 5 Nařízení, rozhodnutí stálé komory o předložení případu k trestnímu stíhání $\mathrm{v}$ jiném členském státě EU, než je stát evropského pověřeného žalobce, který př́ípad projednává, podle čl. 36 odst. 3 Nařízení nebo rozhodnutí stálé komory o spojení několika př́ípadů, v nichž bylo vyšetřování vedeno různými evropskými pověřenými žalobci proti téže osobě nebo osobám, podle čl. 36 odst. 4 Nařízení. Klasický postup, kdy orgán jednoho členského státu EU podá žádost o převzetí trestního řízení a orgán jiného členského státu EU o této žádosti rozhodne, je zde nahrazen rozhodováním stálé komory jakožto orgánu Úřadu, což je umožněno tím, že Úřad vykonává jurisdikce quasi dožadujícího i quasi dožádaného státu. To nepochybně přináší jisté zjednodušení při určení jurisdikce, která má nejlepší předpoklady pro dosažení účelu trestního řízení v konkrétní věci. Skutečnost, že Úřad vykonává jurisdikce členských států EU, pro které je závazné Nařízení, nikoli svou vlastní, se ovšem projevuje mj. v tom, že stálá komora nemá zcela volnou úvahu $\mathrm{v}$ tom, kterému členskému státu EU, pro který je závazné Nařízení, bude věc předána, ale věc může předat pouze tomu z nich, do jehož jurisdikce skutek spadá. Zmíněné typy rozhodnutí stálé komory jsou tedy možné pouze v př́padě pozitivního konfliktu jurisdikcí členských států EU, pro které je závazné Nařízení.

\section{ZÁVĚR}

Úřad je institucí EU se specifickou působností, zaměřenou do vnitrostátní sféry členských států EU, pro které je závazné Nařízení. Tato působnost spočívá v plnění úkolů veřejné žaloby ve vnitrostátním trestním ř́zení namísto vnitrostátních orgánů veřejné žaloby členských státu EU, pro které je závazné Nařízení, ve vztahu k vymezeným trestným činům podle vnitrostátního práva těchto členských států EU poškozujícím nebo ohrožujícím finanční zájmy EU. Úřad tedy má jednotně a koordinovaně vykonávat trestní jurisdikce členských států EU, pro které je závazné Nařízení, v části, v níž tento výkon př́sluší vnitrostátním orgánům veřejné žaloby a v níž tyto trestní jurisdikce chrání finanční zájmy EU.

Tím Úřad vstupuje na pole mezinárodní justiční spolupráce ve věcech trestních, tedy do vztahů součinnosti mezi státy pro účely výkonu jejich trestní jurisdikce, jako nový hráč, který v sobě spojuje dva různé světy - svět EU, jejiž je institucí, a svět vnitrostátních orgánů veřejné žaloby, jejichž působnost má vykonávat.

Jako relativně snadný se tento vstup jeví u vztahů mezinárodní justiční spolupráce ve věcech trestních mezi Úřadem a členskými státy EU, pro které není závazné Nařízení. Je tomu tak díky povinnosti loajální spolupráce podle čl. 4 odst. 3 Smlouvy o EU, kterou mají všechny členské státy EU a která by měla zajistit, aby se tyto vztahy bez problémů

22 Viz SCHUTTE, J. The European System. In: CHERIF BASSIOUNI, M. (ed.). International Criminal Law. Volume II. Procedure. Chapter 5 Transfer of Criminal Proceedings. Dobbs Ferry, New York: Transnational Publishers, Inc., 1986, s. 319. 
dostaly na úroveň mezinárodní justiční spolupráce ve věcech trestních mezi členskými státy EU, prričemž do budoucna lze tuto úroveň ještě zvýšit zvláštní úpravou.

Podstatně složitější bude uspořádání vztahů mezinárodní justiční spolupráce ve věcech trestních mezi Úřadem a jinými než členskými státy EU, vưči nimž EU nemá právní nástroj typu povinnosti loajální spolupráce. Nařízení předpokládá čtyři různé modely uspořádání těchto vztahů, každý z nich je však podmíněn akceptací ze strany daného jiného než členského státu EU, na jehož vưli tedy bude záležet, zda:

- bude ochoten uzavř́ít s EU mezinárodní smlouvu o právní pomoci nebo akceptovat př́stup EU k mezinárodní smlouvě o právní pomoci,

- přijme oznámení Úřadu jako orgánu př́islušného pro účely provádění mezinárodní smlouvy o právní pomoci ze strany členských států EU, pro které je závazné Nařízení, nebo bude ochoten vyjednat s nimi změnu takové mezinárodní smlouvy,

- poskytne právní pomoc Úřadu zastoupenému evropským pověřeným žalobcem, využívajícím svých pravomocí vnitrostátního žalobce, nebo

- poskytne Úřradu právní pomoc v bezesmluvním styku.

V oblasti vztahů mezinárodní justiční spolupráce ve věcech trestních s jinými než členskými státy EU je tedy Úřad nejzranitelnější a bude záležet zejména na politické síle a obratnosti EU, zda přiměje jiné než členské státy EU k přijetí některého z uvedených modeli̊.

Poněvadž Úřad bude vykonávat trestní jurisdikce jednotlivých členských států EU, pro které je závazné Nařízení, bude i vnitřní fungování Úřadu prodchnuto mezinárodní justiční spoluprací ve věcech trestních. U právní pomoci (v užším smyslu) sice Nařízení přináší vlastní mechanismus, nedá se však říci, že by tento nový mechanismus nějak výrazně překračoval stín právní pomoci (v užším smyslu) na základě žádosti nebo evropského vyšetřovacího př́ikazu. Předání osoby zůstává zcela na úrovni obecné spolupráce mezi členskými státy EU, tj. na standardu předávání na základě evropského zatýkacího rozkazu. K největši změně tak zřejmě dochází u předání trestního řízení, jehož mechanismus je v podstatě nahrazen rozhodováním stálé komory, i když půdorys pozitivního konfliktu jurisdikcí zůstává zachován. Právě rozhodování stálé komory, at’ už ohledně určení nejvhodnější jurisdikce, nebo ohledně sporů mezi evropskými pověřenými žalobci z různých členských států EU při uplatňování mechanismu právní pomoci (v užším smyslu), se zdá být nejzajímavější inovací mezinárodní justiční spolupráce ve věcech trestních v rámci Úřadu oproti klasickým mechanismům této spolupráce. Obecně se sice stálá komora jeví spíše jako administrativně byrokratická překážka rychlého a účinného postupu v prípravném řízení trestním, nicméně jako arbitr mezi jednotlivými trestními jurisdikcemi, které bude Úřad vykonávat, oprávněný rozhodovat (narozdíl od Eurojustu, který může jen doporučovat), může být užitečná.

Oproti stávající úrovni mezinárodní justiční spolupráce ve věcech trestních by tak mohlo zř́zení Úřadu znamenat:

- u vztahů mezi Úřadem a členskými státy EU, pro které není závazné Nařízení, v podstatě její zachování a do budoucna možné zlepšení,

- u vztahů mezi Úřadem a jinými než členskými státy EU hrozbu zhoršení, která se (v závislosti na ochotě jiných než členských států EU ke spolupráci s Úřadem) může, ale nemusí naplnit, 
- u vztahů mezi členskými státy EU, pro které je závazné Nařízení, tj. v rámci Úřadu, zlepšení, a to částečně díky úpravě v Nařízení (byt' není př́liš inovativní) a částečně díky tomu, že v rámci jednoho Úřadu lze předpokládat větší ochotu ke spolupráci než v běžných vztazích mezi orgány různých členských států EU.

JUDr. Přemysl Polák, Ph.D.

Nejvyšší státní zastupitelství

PPolak@nsz.brn.justice.cz 